\title{
Language Policy and Planning in Nigeria: The Journey So Far
}

\author{
Acheoah, John Emike \\ Department of European Languages- Federal University- Birnin-Kebbi- Nigeria \\ actualemike@gmail.com
}

\section{Olaleye, Joel Iyiola}

Department of English- Waziri Umar Federal Polytechnic- Birnin-Kebbi- Nigeria

\begin{abstract}
This study is an incisive overview of issues bordering on language policy and planning in multi-lingual Nigeria. British rule in Nigeria marked the beginning of doom for Nigerian languages. This was because English was entrenched constitutionally in sensitive and significant spheres of nation-building: education, administration, politics and international diplomacy. Language policy in Nigeria was partly aimed at assigning roles to the major languages (Hausa, Igbo and Yoruba) so as to curb the excess dominance of English over them. No significant attention was given to the numerous minority languages. In this study, Nigeria's ethnography is not only discussed, but its implications on forward-looking language policy for Nigeria is examined. The study concludes that language problems in Nigeria linger because apart from not being clearly articulated, language policies in post-colonial Nigeria are not implemented with truism and tenacity.
\end{abstract}

Keywords: Language planning, language policy, Nigeria, multilingualism, English, indigenous language

\section{Introduction}

This study engages the concept of language in a multilingual nation. In this regard, Nigeria's language issues are examined within the context of language planning and policy. Dada (2010, p. 417) submits that "language is a unique property that belongs to the human race. It is a means of communication between two or more people and to a very large extent, the development of man politically, socially, economically, etc., depends on the use of language. Indeed, language permeates all aspects of human endeavor. Language is an integral part of culture, a reflection of many features of a given culture thus, like culture itself, it is a leader of behavior, which can be enhanced through direct or indirect contact. The formal and functional complexity of language is such a distinctive human trait that many scholars think the designation "homo loquat" (man the speaking animal) to be a better way of identifying the species than any other simple criterion (Such as tool using) that has been suggested." Given the significance of language in human existence, its implications on nationbuilding, cannot be relegated to the background.

\section{Literature Review}

The literature is replete with critical perspectives on language policy for nation-building. In this section of the paper, we examine the ethnography of Nigeria as well as the implications of the dominance of English over indigenous languages in the country. 


\subsection{Nigeria's Ethnography}

According to Dada $(2010,418)$, "the recent 2005 Ethnologic Data listed 521 languages for Nigeria. Of these, 510 are living languages, 2 are second languages without mother tongue speakers, and 9 are extinct." Research submits that Nigerian languages are grouped as "major languages, state languages and local languages based on their status as dominant languages, their territorial spread and the population that speaks them" (Cf. Brain, 1992, cited in Dada, 2010, p. 418).

On Nigeria's ethnography, Dada (2010, p. 418) reports that "indeed, going by the Ethnologic Data report for Nigeria, some of these five hundred and ten living Nigerian languages have as low as 400-100 speakers. Examples include: Janji, Benue-Congo, language spoken in Bassa LG, Plateau State, Jibe, Afro Asiatic language spoken in Borno State, Ndunda, Nigerian-Congo language spoken in Taraba State etc. Thus, such languages can be rightly categorized without sounding derogatory anyway as minor language used mainly at home, village and local community levels. About 75 percent of the total figures of the Nigerian indigenous languages belong to this core." Igboanusi (2001, p. 13) notes that Nigerian languages are classified into major and minor ones based on: population of speakers, educational consideration, geographical expanse of speaking territories and publications in different disciplines.

\subsection{English in Nigeria}

According to Christine Iyetunde Ofulue (2017, p. 4) "on the African content the implantation and localization of English was one of the major sociolinguistic outcomes of contact with Europe occasioned by trading expeditions, missionary activities, and East Africa are major sites where English has thrived as a direct consequence of British colonization. Its postcolonial history is now more than half a century in countries such as Nigeria, Ghana, Gambia, Tanzania..."

The position of English as the language of instruction in Nigeria is informed by the Education Ordinance of 1882. Thus, in 1896, the Certification System was introduced, and Credit Pass in English became a compulsion in schools. The Article 114(1) of the Littleton Constitution legislated English as an Official Language. As expected, people aspired for mastery in the language that became a major determining factor for success in their career. Positive attitudes towards English propagated it the more in formal education and nationhood. Parents encouraged their children to learn the language. Job opportunities were tied to it. It was a basis for administrative and political appointments.

\subsection{Language Policy and Planning in Nigeria}

Different language policies have been evolved for post-colonial-multilingual Nigeria. Weinstein (1980, p. 56) defines languages planning as "a government authorized long term sustained and conscious efforts to alter a language." For Koul (2006, p. 27) language planning "denotes a deliberate attempt in resoling language-related problems necessary for the development of a particular language." Defining language policy, Akindele and Adegbite (1999, p. 59, cited in Egwuogu, 2017, p. 51) submit that it is "a set of deliberate activities systematically designed to select from, organize and develop the language resources of a community in order to enhance the utilization of such resources for development. Language planning is necessitated by the multilingual states... to integrate the region or country and promote encompassing development."

The 1991 Constitution of the Federal Republic of Nigeria evolved language policy that is widely criticized for its vagueness and non-definitive stance. For example, the two paragraphs below respectively capture Sections Fifty One and Ninety One:

The business of the National Assembly shall be conducted in English and Hausa, Igbo and Yoruba when adequate arrangements have been made. 
The business of a House of Assembly shall be conducted in English but the House may in addition to English conduct the business of the House in one or more other languages spoken in the state as the House may by resolution approve.

Three perspectives that have been evolved as far as language policy in Nigeria is concerned are worthy of scholarly attention (Cf. Morakinyo, 2015, pp. 157-158):

\section{The Nationalist Orientation}

Proponents of the Nationalist Orientation argue that engaging Nigerian language as a National Language to replace English is a nationalist move - an expression of national pride in Nigeria's sovereignty and socio-cultural nuances.

\section{The Internationalist Perspective}

Those who contend for this perspective hold the view that English is neutral and satisfactorily developed to perform two roles: unite the people of Nigeria and cope with the challenges of globalization. The critics of this view believe that the dominance of English in Nigeria is inimical to the future of indigenous languages in the country.

\section{The Neutralist Position}

The Neutralist view is advocated, with the suggestion of Nigerian Pidgin as a National Language due to its neutrality, communicative potential in casual discourses and potency in national cohesion. However, some scholars do not think Nigerian Pidgin is suitable as Nigeria's National Language, given its stigma as sub-standard language.

Language policies evolved so far for Nigeria have not been feasible. Policies should not be evolved for "cosmetic reasons". They have to be viable, potent and forward-looking. Egwogu (2017, Pp. 5456) cites Farinde and Ojo (2005, p. 47) who examine language policies that have been proposed for Nigeria:

\section{The African Option}

Swahili was proposed by Wole Soyinka in 1977 at the International Festival of Arts and Culture (FESTAC). Unfortunately, critics of this proposal hinged their criticism on the fact that Swahili is not a Nigerian language.

\section{The Artificial Option}

There is the belief that an artificial language is ethnically neutral, and can therefore perform a unifying role in multilingual Nigeria. Unfortunately, an artificial language cannot cope terminologically - given its limited lexicon - with the challenges of globalization.

\section{The Endoglossic Option}

A well-developed Nigerian language - in terms of lexicon, grammar and literary publications - is believed to be suitable as a National Language. However, there are those who contend that all Nigerian languages have divisive potential. 


\section{Pidgin Option}

Proponents of Nigerian Pidgin as a National Language strongly hold the view that Pidgin is neutral and is widely spoken across social class. Many scholars agree that it plays vital roles in national cohesion and nation-building.

\section{The Exoglossic Option}

Scholars who contend for an exoglossic option as a language policy for Nigeria, want English to be entrenched as Nigeria's National Language because apart from being void of ethnic sentiments, its vocabulary and grammar are developed. But critics think English remains a colonial heritage, and a danger to Nigerian languages.

\section{The Indexop Option}

Another language policy proposed for Nigeria is the Indexop Policy. Egwogu (2017, p. 56) contends that this policy gives equal opportunities to endoglossic languages in status and corpus planning. See Egwuogu (ibid.) for insights on this policy.

Despite the language policy evolved for Nigeria, English studies have not been impressive. The view has been expressed that failure to use indigenous languages effectively as medium of instruction in schools, is responsible for poor teaching of various subjects including English.

The National Policy on Education (1977) which was revised in 1981 and 2004 legislated the use of the three major Nigerian languages alongside English at different levels of formal education. The role of English was legislated clearly in formal education, but the role of indigenous languages is continually de-emphasized. Below are some of the flaws of the National Policy on Education as cited in Dada (2010, p. 421):

[1] Don't the statements on language constitute just a statement of intent rather than a serious programme for implementation?

[2] If the mother tongue (MT) or the language of the immediate community is considered so important at the pre-primary level as an integral part of the child's culture and the link between the home and the school, why should it be "principal" and not "solely" used at this level?

[3] How do people identify the language(s) of the immediate community in pluralistic settings like urban centres or international communities like universities?

[4] Aren't the pronouncements on the three major languages vague and effeminate?

[5] Further on the choice of language, by whom and at what level is the choice of one of the three languages to be made? By the Federal, State or Local Government? By the parents, the school, or the pupils?

[6] If the government is serious about implementing the policy, shouldn't there be a definite chrogram for all states to follow in the implementation of the language provisions couched in cautious escape phraseology: 'subject to the availability of teachers'?

[7] If the government considers the learning of the three crucial for national integration, where are the legal and other sanctions for defaulting Federal, State and Local Governments or their agencies?

[8] Practically, all Nigerian languages can be used as mother tongues or language(s) of immediate communities. Is it pedagogically feasible to organize initial literacy in 400 odd languages?

[9] How do just three or the major languages serve the need of the educational process and become the media for preserving the people's cultures?

[10] The total number of teachers required in 1988 for the three major Nigerian languages was 55, 237. Only 6,383 or $11.6 \%$ of these were available. How and where are the remaining 48,854 
teachers to be produced? Is the recruitment or training of these teachers to be by chance or to a coordinated programme involving all agencies concerned?

Dada (2010, p. 422) presents the following as the strategies employed by the Federal Government for the implementation of the National Policy on Education:

- $\quad$ L1 Primary School Curricula (NERC, 1982-3);

- $\quad$ L2 and L1 JSS Curricula (NERC, 1982-4);

- $\quad$ L1 SSS Curricula (NERC, 1975-6);

- $\quad$ L1 TTC Curricula (NTI 1986);

- $\quad$ Primary Science Terminology (NLC, 1980-3);

- $\quad$ Legislative Terminology (NLC, 1980-88);

- $\quad$ Metalanguage for the three major Nigerian languages (NERC, 1981);

- $\quad$ Braille Orthography (NERC, 1981-4);

- $\quad$ Orthography Manuals and Pan-Nigerian typographic resources (NLC, on-going);

- $\quad$ L1 Hausa, Igbo, Yoruba SSC Exam Syllabus (WAEC, 1985-6; 1991).

We contend that Nigerian governments at different levels have not taken very serious steps to actualize the goals of language policy, not just in assigning roles to endoglossic languages, but also in terms of corpus and status planning for the "so-called odd languages". Adegbija (1994), cited in Dada (2010, p. 419) asserts that corpus planning includes aspects such as the preparation of orthographies, the commissioning of primers, and the publishing of newspapers in indigenous languages through processes such as compounding, derivation, combination of compounding and derivation, a borrowing in a phonologically adapted form, expansion of meaning of existing words from dialects, lexical change, and spontaneous formation of new words."

\section{Discussion}

Language planning in Nigeria should culminate into the development of the numerous neglected minority languages. Governments at different levels, language experts and concerned Nigerians should contribute meaningfully not only in facilitating the implementation of language policies, but also in the propagation of Nigerian languages. Although some efforts abound in this regard, much more effort is needed to develop and propagate Nigerian minority languages.

To broaden the lexicon of Nigerian languages, scholarly works have been published. Owolabi (2006, pp. 20-22) presents the following:

[1] A Glossary of Technical Terminology for Primary Schools in Nigeria (henceforth, GTTPSN).

The GTTPSN comprises mathematical and scientific terms in Edo, Efik-Ibibio, Hausa, Igbo, Izon (a form of Ijo), Kanuri, Yoruba and Tiv. Areas covered by the work, which was sponsored by the Federal Ministry of Education, are sets, numbers, operations, geometry, measurement, physical science and biological science.

[2] Metalanguage (henceforth, ML): There is ML for each of Hausa, Igbo and Yoruba for the purpose of facilitating the teaching and learning of each of these three languages in its own medium. The terms cover various aspects of linguistics (e.g. phonetics, phonology, syntax, sociolinguistics, etc.) as well as stylistics, literature (including culture) and methodology. The project was sponsored by the Nigerian Educational Research Council (NERC), now (NERDC).

[3] A Quadrilingual Glossary of Legislative Terms (henceforth QGLT): The QGLT is an assemblage of terms in English and their equivalents in Hausa, Igbo and Yoruba. The Project, which was facilitated by the Nigerian Educational Research and Development 
Council (NERDC), covers a wide range of areas which legislative discourse can be centred on (e.g. education, politics, revenue collection and allocation, industrial, commercial or agricultural development, information, sports, etc.).

[4] Yoruba Dictionary of Engineering Physics (henceforth, YDEP): YDEP is a bilingual EnglishYoruba/Yoruba English dictionary. Apart from its main entries on Engineering Physics, the dictionary also contains entries on physical laws, rules, theorems and principles as an appendix.

If all Nigerian languages are developed, learning them in schools will be easier and more goaldriven; English is fortunate in this regard. Dada (2007) submits that the reasons why Nigerian are not learning any other indigenous language in addition to their mother tongue are that:

- English is compulsory for every Nigerian, being the de Facto official language in the bureaucracy and all tiers of formal education in Nigeria and as an international language for that matter.

- The utilitarian value (socially, economically and academically) of the English language vis-àvis any of our indigenous languages is high.

- The over bearing status of the English language over the indigenous languages in Nigeria today makes even mother tongue learning a perfunctory exercise.

In addition to the above submission, Dada (2010, Pp. 429-430) states that "the Imo State government set up a "Panel on the Teaching of Igbo, the Imo State School System and the Implementation of the National Language Policy". The panel observed that although there are appreciable changes since 1986 with regard to the policy on Igbo in particular and languages in general but the cogent lapses noticed included:

[1] Lack of awareness on the part of highly placed ministry officials (Supervisors/Inspectors of Education, Principals/Headmasters of Schools and practicing teachers) of the language policy as stated in the NPE. And that this lack of awareness is responsible for the relatively inferior status accorded Nigerian languages in the school system in particular and the society in general. Igbo is not being taught or tolerated in most nursery schools in the state, nor is it being seriously and consistently used as the medium of instruction in the junior primary classes. Again Igbo is not being seriously taught as 'core' subject, as the NPE stipulates, in the upper primary classes through to the secondary school where it has fewer periods a week on the time table than any other subject in the curriculum.

[2] Under-utilization of trained teachers and even inadequacy of trained teachers that is, in spite of the imitable efforts of the Colleges of Education of Owerri, Awka, Nsugbe, Ehamufu, Okere and Abeokuta to produce NCE teachers of Igbo for the school system.

Egwuogu (2008, p. 15), cited in Egwuogu (2017, p. 48) reports that "the three major indigenous languages enjoy greater prominence in the national life of the country than others as each is spoken as Mother Tongue (MT) in not less than seven out of the 36 States of the Federation. The minority languages are used for local communication, being restricted to the primary domains of life (Webb, 1994, p. 181) such as informal or interpersonal relations, local markets, traditional social institutions and religion (Igboanusi, 2002, p. 13). However, some of them occupy important positions as they are seen beyond the country e.g. Fulfulde, or studied as subjects in schools e.g. Efik. The fact that the major languages in Nigeria have been significantly developed in terms of their lexicon, grammar and literature, makes it logical to conclude that the neglected ones have the potentials to be developed; their internal systems are not strange. Indigenous languages are being used for radio and television broadcast. Furthermore, advertisements are carried out in some of these indigenous languages and even the print media e.g. newspapers and published in them, especially the big three." 
Indeed, the non-incorporation of most Nigerian languages in formal education has not facilitated the learning of English to the expectation of the school system. If English is to serve its purpose as Official Language or National Language, the "quality" of Standard Nigerian English should not be too different from its matrix, Standard British English, particularly at the phonological level of analysis. Unfortunately, many Nigerian graduates do not demonstrate expected competence in English. Commenting on poor English studies in Nigeria, Ayansola Abayomi (2017, pp. 60-60) reports that "because we can't get inside their heads to find out what they truly know and what they don't we can look at samples of their behavior. What they write, produce, say and perform, and from these samples estimate or infer what they truly know (Suskie, 2009, p. 37)." According to Clement Gowon Omachonu et al. (2017, p. 168) "the use of English as a global lingual franca requires intelligibility and the setting and maintenance of standards. On the other hand, the increasing option of English as a Second Language (ESL), where it takes on local forms, is leading to fragmentation and diversity. No longer is it the case, if it ever was, that English unifies all who speak it (Gradual, 2000). The competing trends will give rise to a less predictable context within which the English language will be learned and used." We do not align with the idea that knowledge of indigenous languages cannot be used to promote the teaching and learning of English in educational institutions. The continued neglect of indigenous languages in language planning in Nigeria is unacceptable. Salawdeen and Hamzah (2016) advocate for "a multilingual policy, backed by legislation, that would empower other languages, particularly the major-minority languages so that they would be used as media of instruction from pre-primary to primary levels, and as teaching subjects from JSS to SSS levels." In addition, they recommend a Credit pass in one of the major indigenous languages as a basic requirement for admission to tertiary institutions, irrespective of any course of study or discipline. Salawdeen and Hamzah (ibid.) cites that "most countries willing to be detached from the yoke of linguistic imperialism have used the opportunity of independence to assert their authority by declaring an indigenous language as national/official language as we have in the case of Sudan in 1956 which declares Arabic as official language and Tanzania in 1961 with the declaration of Swahili." It is clear that indigenous languages in Nigeria have not been rescued from the dominance of English due to lack of concern from governments and individuals. Salawu (2006, p. 2) submits: that "for any African that is concerned for the soul and survival of his language, there must be a deliberate and sincere effort to learn and teach the language..." For several decades, language attitudes have impacted negatively on Nigerian languages. Language attitudes are inimical to language planning. Adegbija (2004, p. 54) submits:

Attitudes towards languages are motivated by several factors including their socioeconomic value, their status-raising potentials, their perceived instrumental value, their perceive esteem, their perceived functions or roles in the nation, their numerical strength, the perceived political and economic power of its speakers, their use in the official domains, their educational value, etc. Generally, positive attitudes, covert or overt, are developed towards a language that is perceived to have value in all these different areas ... Conversely, negative attitudes, overt or covert, develop towards a language in proportion to its lack of function or narrowing or narrowing of its distribution in registers.

Commenting on the relegation of Nigerian languages, Acheoah and Abdurraheem (2017, pp. 1-9) submit:

The age-long, tenacious cleavage which Nigerian languages have in oral tradition is believed to be the reason for low literacy in mother tongues. Since indigenous languages are strongly rooted in society, they can facilitate English studies in Nigeria if only adequate and appropriate steps are taken by government, schools and researchers to revive them. Scholars note that although Chinua Achebe's Things Fall Apart was translated into 54 languages across the world, one does not know of any 
Nigerian language that the novel was translated into. Why can't Nigerian writers become literates in mother tongues, thereby articulating their literary ingenuity in indigenous languages?

A forward-looking language policy for Nigeria, is indeed, urgent. However, as scholars have noted, the psychological context, must not be ignored in the formulation and implementation of language policies in the country. This view corroborates Bello, Ahmadu and Bulkarima (2008, p. 4) who note that "in the Nigerian experience, most conflicts can be somehow linked to identity or ethnicity, the strong index of which is language."

John Walsh posits that "because of importance of education in facilitating a community's socio-economic development... it was highly significant that a major global institution gave its blessing to the presence of vernacular languages as media of instruction in the education system (John Walsh, 2006, p. 129)." The potency of indigenous languages in the transmission of knowledge and overall growth of a nation is understandable if one considers the submission of Schlesinger (1991, pp. 2-13) who opines that "a key contribution from linguistics to the debate over the role of language in development is the argument that language influences cognition and is linked intimately to culture. The idea that language is a formative factor in the culture of its speakers is not new: it came into its own in the work of Enlightenment figures such as Johann Gottfried Herder, who claimed that there was a 'parallelism' between the thoughts of a nation and its language, and that language was the medium through which culture was transmitted." Adeniran, cited in Ayodabo (2013, p. 213) opines that "in general, communication promotes the immediate and ultimate developmental aims of society via its systems of collection and dissemination of information in support of individual and community activities. It fosters social cohesion at the community level. People get to understand each other and to appreciate other people's living conditions, viewpoints and aspirations. They... are able to react knowledgeably to issues in ways that should facilitate appropriate decisions geared to the realization of agreed objectives."

A lot of critical perspectives abound on the credentials of indigenous languages. Ayodele Christiana Ayo and Obateru Oluwatoyin (2017, pp. 69-70) present comprehensive remarks on Nigerian languages:

David (2006) describes the indigenous language as a language that is considered to be spoken by the inhabitants of an area and which this group of people acquired in their early years and that this language normally becomes their national instrument of thought and communication. It can also be described as the language that one learns in his immediate speech community and uses as language of intimacy. It is the tool for developing our self-image and self-worth not only as individual but as a nation, a people and civilization. The indigenous language is considered to be very vital in African education as a means of preserving the custom, value and tradition of the people. The Phelp's Stoke Commission reported that in view of the assessment of the language needs of African child, English and indigenous languages were recommended to be used in the school system with emphasis on the role of the mother tongue in the education of an individual child. The commission equally reported that, indigenous African language should be given pride of place as medium of instruction of African school age. It was the belief of the commission that people have an inherent right to their own language. It is a language of intimacy. Babalola (1988) believes that the privilege of learning the indigenous language should not be withheld from the native child. A child that is literate in the indigenous language will be sufficiently equipped to live a useful and successful life in this changing world. Bamgbose (2004) posits that a meaningful education can be achieved when the child's mother tongue is used as the medium of instruction.

The use of the indigenous language can aid the children's ability to think and 
organize information while in school. The language can assist in the total growth and development of a child. An individual child is able to develop into maturity through the indigenous language. There is a general view that people use their indigenous language for close interaction with peers, family from cradle to old age. Fafunwa (2004) believes that, it is through this language that thought occurs. The language is also used to teach the students moral and ethics of good behaviour which is held in high esteem in the African set up. The indigenous language is well known as the identity of the ancestors. It is through this language that the listener is able to understand, interpret and make relevant meaning and contributions to any expression."

This study does not oppose the accommodation of English in Nigeria. The roles assign to the language are products of its global status. In a multilingual country like Nigeria, a framework for the co-existence of English with indigenous languages should be evolved. Adeniran, cited in Ayodabo (2013, p. 159) submit that "since in a national language policy for one political entity which is the Nigerian nation, it is operationally impossible to assign the same and equal roles to all these languages, a well-considered strategy becomes necessary for distributing roles among the languages. In this, there appears to be three options open:

- Maintain the status of one, whereby exoglossic English, but none of the indigenous languages (with the possible exception of Hausa in its northern domain) performs all the official roles, and is the medium of technical and higher education;

- Work headlong for the adoption of one or more indigenous languages as national and possible official language to the exclusion of any foreign language;

- In realistic terms, adopt a kind of pluralist language policy which contains but balances the elements of (a) and (b)."

For effective, result-driven language planning, the notion "language planning" has to be properly understood by stakeholders.

\section{Conclusion}

Unless the stigma attached to indigenous languages is revisited, relevant roles cannot be assigned to them in nationhood, particularly the minority ones. The potentials of Nigerian languages have been acknowledged by different scholars. For instance, Ali Mazrul (1974) cited in Ayodabo, (2013, p. 191) contends that "it would be wrong to say the African languages are barrier to the teaching of science and technical subjects. The syntactical structure of those known to me would not provide any major obstacle to the pursuit of logical reasoning..."

The description of minority languages as "odd" is unacceptable; Indeed, linguists hold the view that no language is inferior, so long as the language is efficient in communicating the needs of its speakers. It is therefore unfortunate that critics of the National Policy on Education are also attitudinally part of Nigeria's language problems! The government alone cannot solve language problems in any nation.

The study discusses language policy options that have been evolved for Nigeria and the constraints of such policies. Indeed, the sensitivity and importance of language in nation-building have to be acknowledged before any meaningful step can be taken to address language problems and language-based problems in multicultural and multi-ethnic Nigeria. 


\section{References:}

[1] Acheoah, J. E. \& Abdurraheem. H., The instrumentality of indigenous languages in English studies in Nigeria, American Research Journal of English and Literature, 3(1)(2017), 1-9, https://doi.org/10.21694/2378-9026.17011

[2] Adegbija. E. F., Language policy and planning in Nigeria, Current Issues in Language Planning, 5(3) (2004), 181- 246, https://doi.org/10.1080/14664200408668258

[3] Ayansola. A. O., Employers' graduate ratings appraisal of the NUC BMAS in English studies in Nigeria, JESAN, 19(2)(2017), 62-63.

[4] Ayodabo. J. O., Linguistic and sociolinguistic situation in Nigeria, Ilorin. Haytee Press, (2013)

[5] Ayodele. C. A. \& Obateru. O., A survey of the usage of English language and the prospect of the indigenous language in Nigeria, JESAN, 19(1)(2017), 69-70.

[6] Bello. B. M., Ahmadu. H. J. \& Bulakarima. S. U., Harnessing the potentials of language and culture for conflict resolution and management in Nigeria. Paper presented at the 22nd Conference of the Linguistic Association of Nigeria held at the University of Maiduguri 9-13 November, (2008).

[7] Clement. G. O., Joseph. A. \& Oma. A. H., Repositioning English pedagogy in Nigeria for autonomy in the context of globalization, JESAN, 19(2)(2017), 167-177.

[8] Dada. S. A., Language policies and planning in Nigeria: Issues and perspectives, JESAN, 13(2) (2010), 417-440.

[9] Egwuogu. C. B., Revisiting the need for a strategic language policy and planning in Nigeria, JESAN, 19(2)(2017), 15-48.

[10] John. W., Language and socio-economic development: towards a theoretical framework, Language Problems and Language Planning, 30(2)(2006), 127-148, https://doi.org/10.1075/lplp.30.2.03wal

[11] Koul. N. O., Language planning in a multilingual situation. In S. M. Kembosure \& O. O. Nathan (Eds.), Language planning for development in Africa. Moi. Moi University Press, (2006)

[12] Morakinyo. O., Language policy in Nigeria: Problems, prospects and perspectives, International Journal of Humanities and Social Science, 5(9)(2015), 154-160.

[13] Ofulue. C. I., English and its offspring: An exploration of socio-historical trajectories, alternative perspectives, and contemporary language practices in a postcolonial context, JESAN, 19(2)(2017), 1-27.

[14] Salaudeen. W. O. \& Hamzah. A., The withering tongues: empowering Nigerian languages in the face of global challenges. In O. Ayodabo, U. Nahum \& E. P. Ona (Eds.), Lokojja. Department of English and Literary Studies, Federal University Lokoja, (2016), 466-478.

[15] Salawu. A., Indigenous language media: A veritable tool for African language learning, Journal of Multicultural Discourses, 1(1)(2006), 86-95, https://doi.org/10.1080/10382040608668533

[16] Schlesinger. I. M., The wax and wane or Whorfian views. In: R. L. Cooper \& B. Spolsky (Eds.), The Influence of language and culture and thought: Essays in honour of Joshua A. Fishman's sixty-fifth birthday. Berlin \& New York. Mouton de Gruyter, (1991), 7-44, https://doi.org/10.1515/9783110859010-002

[17] Weinstein. B., Language planning in francophone Africa, Language Problems and Language Planning, 4(1)(1980), 55-77, https://doi.org/10.1075/lplp.4.1.04wei 